The following is an electronic version of an article that will appear in Intellectual History Review, 2012

\title{
Language, reason, and sociability: Herder's critique of Rousseau
}

Johann Gottfried Herder's Treatise on the Origin of Language (1772) is about much more than the origin of language. The secondary literature has tended to focus on the latter, ${ }^{1}$ and while this has been changing in recent years, especially in the German scholarship, there has still been no study which adequately exposes 1) what Herder is actually doing in the treatise as a whole, and 2) how it fits into his wider philosophy. ${ }^{2}$ This article is intended to be a contribution towards achieving these objectives. It seeks to show how the Treatise can be illuminatingly seen as a sustained response to the challenge laid down by Rousseau in his Discourse on the Origin of Inequality with respect not just to the origin of language, but to the connections between language, reason, and sociability. Central to this enterprise is Herder's rejection of the notion of réflexion en puissance (the potential for reflection) and his argument for natural sociability in Part II of the Treatise, which has received scant attention in the secondary literature. Informing Herder's theory is a conception of the soul as consisting of a set of forces which necessarily unfold themselves, and here the Treatise connects up with his notion of natural law and with his conception of nature and the physical world as the external manifestation of the divine thought that is equally involved, qua natura operativa ${ }^{3}$, in a process of unfolding. ${ }^{4}$

\section{The Language of Feeling}

Herder's theory of the origin of language starts from a distinction central to eighteenth century reflections on human nature, namely, that between humans and animals. The question

\footnotetext{
${ }^{1}$ Herder was well-acquainted with the debate in the Berlin Academy on the origin of language that had been raging for more than two decades and with Johann Süßmilch's theory of a direct divine origin, which prompted the Academy's prize question on the issue which Herder won with his Treatise. For background, see the classic study by Hans Aarsleff, "The Tradition of Condillac: The Problem of the Origin of Language in the Eighteenth Century and the Debate in the Berlin Academy before Herder," in Studies in the History of Linguistics:

Traditions and Paradigms, ed. Dell Hymes (Bloomington: Indiana University Press, 1974), 93-156, here 12138; and, more recently, see Cordula Neis, Anthropologie im Sprachdenken des 18. Jahrhunderts: Die Berliner Preisfrage nach dem Ursprung der Sprache (1771) (Berlin: de Gruyter, 2003).

${ }^{2}$ Noteworthy are the excellent studies and commentaries by Ulrich Gaier and Wolfgang Pross. See Ulrich Gaier, "Kommentar", in Herder, Frühe Schriften (1764-1772), ed. Gaier (Frankfurt: Deutscher Klassiker Verlag, 1985), 1274-1328 and Gaier, Herders Sprachphilosophie und Erkenntniskritik (Stuttgart-Bad Cannstatt: frommann-holzboog, 1988), 75-156; Wolfgang Pross, "Kommentar", in Herder, Abhandlung über den Ursprung der Sprache, ed. Pross (Munich: Carl Hanser Verlag, 1978) and Pross, "Kommentar", in Herder, Herder und die Anthropologie der Aufklärung, ed. Pross (Munich: Carl Hanser Verlag, 1987), 895-983; hereafter "Kommentar (1987)".

${ }^{3}$ The term derives from Friedrich Heinrich Jacobi's 1773 review of the Treatise in which he accused Herder of subordinating humans and human freedom to the blind necessity of an albeit systematic natura operativa. See Pross, "Kommentar (1987)", 915.

${ }^{4}$ I explore Herder's theory of the soul in greater detail in DeSouza, "Leibniz in the eighteenth century: Herder's critical reflections on the Principes de la nature et de la grace", British Journal for the History of Philosophy, forthcoming.
} 
of whether animals have souls, while the subject of intense debate ever since Descartes' claim that they did not and were mere machines ${ }^{5}$, was no longer relevant for Herder, who accepted that they did (along with Rousseau and Condillac). ${ }^{6}$ The animal-human distinction now centred rather on how to conceive what was distinctive about the human soul, given that animals shared many of the same faculties, such as sensation, imagination, and representation. For Herder, as we shall see, it was the different organization of the soul's forces in animals and humans that accounted for the distinction, an organization apparent from the very beginning of human development. Herder opposed his conception of the distinction to one which claimed it consisted in the human soul possessing additional forces or capacities that could remain dormant or in a state of potentiality until triggered into activity. This was the conception Herder associated with Rousseau and Condillac. Condillac's account, which Rousseau followed ${ }^{7}$, of how language, and with it reflection, might have arisen "by natural means" (as opposed to the official account of divine instruction), imagines two post-diluvian children in a desert whose mutual discourse leads them to connect the naturally spontaneous cries of passion and feeling with the perceptions associated with them, e.g., a piece of fruit out of reach, the encounter of a dangerous animal, etc., and then to begin to use them with intention as "instituted signs". ${ }^{8}$ Herder fundamentally disagreed with this account and had to show why it was mistaken before he could present his own.

Herder's disagreement was not, however, wholesale. It was premised on a distinction between a language that humans shared with animals and a language that was specifically human - and Condillac's cry of passion had everything to do with the former and nothing to do with the latter. The very opening of Herder's Treatise sets the scene: “Already as an animal, the human being has language." That language is the language of feeling, which consists in the need that humans and animals both share to express intense or painful bodily

\footnotetext{
${ }^{5}$ For discussion, see Jean-Luc Guichet, Rousseau, l'animal et l'homme. L'animalité dans l'horizon anthropologique des Lumières (Paris: Cerf, 2006), 25-111 and Neis, Anthropologie, 195-231.

${ }^{6}$ See Condillac, Essay on the Origin of Human Knowledge, ed. Hans Aarsleff (Cambridge: Cambridge University Press, 2001), 39; hereafter Essay. Unlike Condillac, who argued against Buffon for their existence, Rousseau's belief in animal souls, like Herder's, is simply assumed; see, e.g., Rousseau, Lettres morales, in Euvres complètes, vol. IV, ed. Bernard Gagnebin and Marcel Raymond (Paris: Gallimard, 1969), 1098. For discussion see Guichet, Rousseau, l'animal et l'homme, 129-70 and Victor Goldschmidt, Anthropologie et politique. Les principes du système de Rousseau (Paris: Vrin, 1983), 273-88.

${ }^{7}$ Rousseau, Discourse on the Origin of Inequality, in The Discourses and Other Early Political Writings, ed. Victor Gourevitch (Cambridge: Cambridge University Press, 1997), 145ff.; hereafter Discourse.

${ }^{8}$ Condillac, Essay, 113-15.

${ }^{9}$ Herder, Treatise on the Origin of Language, in Johann Gottfried von Herder: Philosophical Writings, ed. Michael N. Forster (Cambridge: Cambridge University Press, 2002), 65. Modifications of this translation are based on the German text in Gaier, Frühe Schriften. Hereafter Treatise.
} 
sensations or strong passions in "cries, tones, in wild unarticulated sounds". ${ }^{10}$ Herder immediately situates this language of feeling within a conception of a natura operativa or "würkende Natur" (active nature). Nature, he says, has hardly made us to be "egoistic monads", referring to his belief in the naturalness of interaction and communication among animals and humans, but also playing on his rejection of Leibnizian pre-established harmony and concomitant acceptance of soul-body interaction. ${ }^{11}$ Rather, nature has connected creatures with one another via a natural law according to which vivid sensations must be vocalized. "These groans, these tones are language. Hence there is a language of sensation which is an immediate law of nature." 12 This law operates on a physiological level, at the level of the nervous structure of organisms, in a manner Herder regrets is still too inadequately understood. The metaphor he employs to illustrate how this language works is of musical strings: the finest cords of animal feelings necessarily produce sounds that arouse a sympathetic feeling in creatures of the same species, who are similarly delicately strung (zartbesaitet), without any conscious intention to do so on the part of the vocalizing creature. ${ }^{13}$ Evolving out of this, each animal species has its own more developed language of feeling which Herder calls a "language of a people" or Völkersprache, through which they communicate in their own limited manner. ${ }^{14}$ Human beings, too, have such a language whose sounds Herder associates with interjections we still use meaningfully, such as "Ah!" (melting love or sinking despair) and "Oh!” (sudden joy or impetuous fury). ${ }^{15}$

The sounds of this language, however, are not where the origin of the language of words is to be found. "They are not the actual roots, but the juices which enliven the roots of language." $" 16$ Beyond its function as a source and means of affective connection between creatures, the language of feeling is an important precursor to the emergence of the language of words, or what Herder calls "human language". The very act of vocalizing strong sensations or passions serves to develop and train the physiological infrastructure that spoken human language will utilize and provides it with its sonic "raw materials". ${ }^{17}$ But even before the emergence of spoken language, the language of feeling lays groundwork for the true origin of human language (which, as we shall see, is not originally spoken language), and it is

\footnotetext{
${ }^{10}$ Ibid.

${ }^{11}$ See Herder, Über Leibnitzens Grundsätze von der Natur und Gnade, in Herder und die Anthropologie, ed. Pross, 49-51. For discussion, see DeSouza, "Leibniz in the eighteenth century".

${ }^{12}$ Herder, Treatise, 66.

${ }^{13}$ Ibid., 65, 66.

${ }^{14}$ Ibid., 67.

15 Ibid.

16 Ibid., 68.

${ }^{17}$ Ibid., 69.
} 
here that Herder parts company with Condillac and Rousseau and all other previous language theorists. In order to see how, we need first to return to Condillac's theory. In his Treatise, Herder targets what he sees as the fatal weakness of Condillac's theory: how do the two children in the desert make that jump from spontaneously emitting cries of feelings to using them with intention, from the unconscious use of natural signs to the conscious use of instituted ones? ${ }^{18}$ Condillac had himself recognized, and admitted in letters to Pierre Louis Moreau de Maupertuis ${ }^{19}$ and Gabriel Cramer, that his theory was inadequate, saying he had given "too much to signs" and not enough to the role of social interaction (commerce). In one such letter to Cramer, he writes: "[t]his commerce provides the occasion 1) to change natural cries into signs, 2) to invent other signs which we call arbitrary; and these signs (the natural as much as the arbitrary) are the first principle of the development and progress of the operations of the soul." ${ }^{, 2}$ This admission, however, did nothing to rectify the problem, as Herder saw it. For the question of precisely how arbitrary/instituted signs begin to be used is not answered by asserting that interaction provides the occasion to do so.

\section{Language and Sphere}

The linchpin in Herder's theory of the origin of language is his alternative explanation of how instituted signs, or their equivalent, arise. And the starting point for Herder is the difference between the soul-forces (Seelenkräfte) of animals and humans. Animals closer to us in nature have many of the same faculties, such as sensation, imagination, and representation. But whereas we have a further capacity for reason and language, animals are confined to instinct. This formulation, however, is problematic; for the error of Condillac and Rousseau, in Herder's eyes, lies in construing reason and language as just this - a further capacity that is added to the capacities we share with animals and that requires other "arbitrary or social forces" to develop. ${ }^{21}$ Herder resolutely rejected the faculty psychology of his day, which divided the soul into imagination, understanding, representation, reflection, etc. These divisions are made for our own convenience, he insists, given our inability to perceive the "faculties" simultaneously; in reality, "the whole undivided soul operates" (würkt). ${ }^{22}$ Herder's claim is that reason and language are the product of a qualitative, not

\footnotetext{
18 Ibid., 75.

${ }^{19}$ Cuvres philosophiques de Condillac, ed. Georges Le Roy (Paris: Presses Universitaires de France, 1947-51), vol. 2, 563.

${ }^{20}$ Condillac, Lettres inédites à Gabriel Cramer, ed. Georges Le Roy (Paris: Presses Universitaires de France, 1953), undated letter but after 1750, 86 .

${ }^{21}$ Herder, Treatise, 81-2 (translation modified).

${ }^{22}$ Ibid., 83 (translation modified), 134.
} 
quantitative, difference in human soul-forces, as compared with those of an animal. He unpacks the nature of this difference through some critical reflections on Hermann Samuel Reimarus' General Observations on the Instincts of Animals, Chiefly on Their Instincts to Art (1760). Reimarus distinguishes between mechanical instincts, representational instincts, instincts of affect, and instincts to art. The first refer to the basic operations of the body, such as breathing and circulation. Representational instincts depend on the sense organs, nervous system, and brain and involve perception and sensation. Instincts of affect concern the passions, such as pleasure and aversion. Finally, instincts to art involve what normally goes under the name 'instinct', i.e., animals' innate skills in securing food, building a home, etc. ${ }^{23}$ Reimarus claims that humans and animals share the first three, but that only animals have instincts to art. Humans may possess some form of these (such as suckling as an infant), but they mostly lack them. Reimarus also maintains that there is no further explanation for animals' innate instincts to art, which they follow blindly, than the will of God who endowed animals with these basic forces (Grundkräfte). ${ }^{24}$

Herder takes issue with this latter claim of Reimarus', arguing that to assume blind determinations destroys all philosophy. ${ }^{25}$ Instead he creatively utilizes elements from Reimarus' own theory to provide a more satisfactory explanation of the presence of instincts to art in animals and their absence in human beings. To be sure, Herder does not dispute that animals (and humans) owe their endowment of basic forces to God; rather, he wishes to provide a naturalistic understanding of just how those forces develop. ${ }^{26}$ In a word, Herder draws a connection of dependence between the representational instincts of animals and their instincts to art: "it is possible 'to explain all drives to and abilities for art from animals' forces of representation". 27 The key to understanding this connection is the concept of "the sphere" of an animal, which Herder most likely also takes from Reimarus. ${ }^{28}$ Every animal has

\footnotetext{
${ }^{23}$ Reimarus, Allgemeine Betrachtungen über die Triebe der Thiere, hauptsächlich über ihre Kunsttriebe (Hamburg: Johann Carl Bohn, 1760), 1ff., 16ff., 73ff., 87ff.

${ }^{24}$ Ibid., 69-70, 365, 373.

${ }^{25}$ Herder, Treatise, 79. Moses Mendelssohn made this very point in his 1761 review of Reimarus' book, arguing that Reimarus needed to show how instinct could be explained through the nature of the animal soul. See Literaturbriefe, 130. Brief, in Moses Mendelssohn's gesammelte Schriften, ed. G. B. Mendelssohn (Leipzig: Brockhaus, 1844) vol. 4, part II, 184-85. Reimarus responded to Mendelssohn's criticisms in a second edition in 1762 in a long appendix, but curiously still maintained, repeatedly, that animal instinct must be "eine blindlings determinirte Neigung zu einer gewissen Wirksamkeit". He acknowledged that Mendelssohn criticized him for giving no further ground for the exact determination of these forces but replied that if clear experiences and correct conclusions show the determination of natural forces are original and essential, then a philosopher is entitled to claim there can be no further ground, except the will of God. See Anhang von der verschiedenen Determination der Naturkräfte, in Allgemeine Betrachtungen (Hamburg: Johann Carl Bohn, 1762), 29, 61-2.

${ }^{26} \mathrm{My}$ thanks to the anonymous reviewer for encouraging me to be clearer on this point.

${ }^{27}$ Ibid.

${ }^{28}$ Ibid., 78; Reimarus, Allgemeine Betrachtungen (1760), 382.
} 
a sphere or circle (Herder uses these synonymously) which it is born into and remains in for its whole life. There exists, Herder claims, an inverse proportion between the extent of this sphere and the degree to which a creature is governed by instinct. This degree is in turn directly rooted in the representational range of the animals' soul-forces.

When infinitely fine senses are confined to a small circle, to uniformity, and the whole remaining world is nothing for them, how they must penetrate! When forces of representation are confined to a small circle and endowed with an analogous sensuality, what effect they must have! And finally, when senses and representations are directed at a single point, what else can become of this but instinct? ${ }^{29}$

Herder also draws a connection between the size of an animal's sphere and the extent of its language (and here he moves beyond Reimarus): the smaller the sphere, the less extensive the language. For besides the language of feeling - "the sounding forth of the sensitive machine" ${ }^{, 30}$ - Herder attributes to each animal species an animal language "which is appropriate for its sphere of needs and types of work, for the organization of its senses, for the direction of its representations, and for the strength of its desires." ${ }^{31}$ In the background of this discussion is Leibniz-Wolffian epistemology and the spectrum of ideas ranging from obscure and confused to clear and distinct. Animal species demonstrate an "obscure, sensuous common-understanding among its members about its destiny in the circle of its efficacy (Würkung)". ${ }^{32}$ Animals are confined to some kind of limited sphere and their languages are correspondingly more or less obscure, but always only obscure. ${ }^{33}$

This proportionality between sphere and language seems to disappear in the case of humans for the simple reason, Herder observes, that the human being has no language that is as instinctive to it as those of each animal species. ${ }^{34}$ The reason is to be found in the fundamental difference between the human sphere and all animal spheres.

The human being has no such uniform and narrow sphere where only a single sort of work awaits him; a world of occupations and destinies surrounds him. His senses and organization are not sharpened for a single thing; he has senses for everything and hence naturally for each particular thing weaker and duller senses. His forces are distributed over the world; [there is] no direction of his representations towards a single thing; hence no drive to art, no skill for art - and, one thing which is more especially relevant here, no animal language. ${ }^{35}$

\footnotetext{
${ }^{29}$ Herder, Treatise, 79.

${ }^{30}$ Ibid.

${ }^{31}$ Ibid., 80. This animal language is most likely the Völkersprache Herder describes earlier.

${ }^{32}$ Ibid., 79.

${ }^{33}$ Ibid., 80 .

${ }^{34}$ Ibid.

${ }^{35}$ Ibid., 79. Cf. Astrid Gesche, Johann Gottfried Herder: Sprache und die Natur des Menschen (Würzburg: Königshausen und Neumann, 1993),117-25. Gesche recognizes the centrality of Herder's critique of Reimarus and the intimate connection between language and sphere, and hence the inadequacy of animal language for
} 
The result is that a newly born child is in a state of seeming helplessness. Invoking the image of misericordia so central to the modern natural law tradition, Herder bemoans the predicament of this "naked and bare, weak and needy, timid and unarmed [...] most orphaned child of nature". ${ }^{36}$ Rousseau, of course, vehemently argues against this portrayal in Part I of his Discourse on the Origin of Inequality. Herder, too, rejects it-"No! Such a contradiction is not nature's way of organizing her household!"-and his reasons for doing so will become the basis of his critique of Rousseau.

\section{The Origin of Human Language}

Given the indeterminacy of the human sphere, a language is needed which sorts through the infinite wealth of data that flood the individual's senses. No animal language will do, because these are oriented towards senses already focussed within a limited sphere. Rather, the key to this language is found in the source of the indeterminacy: the soul-forces of the human being are organized differently from the soul-forces in animals. Instinct results from the determinate organization of these forces, which entails that of the senses and representations too. ${ }^{37}$ The lack of determinate organization in human soul-forces translates into human freedom: "no longer an infallible machine in the hands of nature, he becomes his own end and goal of refinement." 38 But to realize this end/goal, the "free-standing" human being, deprived of instinct, requires a way to bring order to the sensations it receives from the surrounding world. And it is the very organization of soul-forces responsible for human freedom that also gives rise to a state only humans possess, constituting nature's compensation for their lack of instinct: the state of reflective awareness or Besonnenheit. ${ }^{39}$ This state will eventually lead to actual reflection (Besinnung) and language. Herder's originality, however, consists in postulating a two-stage approach. What defines the state of reflective awareness is its active presence from the outset. ${ }^{40}$ Just as an animal's determined soul-forces are expressed as instinct from the very beginning, the undetermined nature of human soul-forces manifests itself as reflective awareness from the start. The flooding of the

\footnotetext{
human beings, but does not go on to show precisely how human language meets this adequacy requirement and is commensurate with the human sphere. We turn to this question in the next paragraph.

${ }^{36}$ Ibid. 80 . We return to the image of misericordia and the modern natural law tradition below in the discussion of Part II of the Treatise.

${ }^{37}$ Ibid., 82 .

${ }^{38}$ Ibid.

${ }^{39}$ Ibid., 84. Wolfgang Pross links Herder's avoidance of the more obvious German term, Aufmerksamkeit, in part to the latter's association in the work of Johann Georg Sulzer with a separate faculty of the soul, which Herder rejected. See Pross, "Kommentar (1987)", 955-56.

${ }^{40}$ Ibid., 85.
} 
senses by the external world immediately activates the individual's sensorium commune (i.e., the inner sense which is common to all senses), for the various senses are merely forms of representation of the undivided soul. ${ }^{41}$ The soul is now in a state of reflective awareness, ready for the trigger that will begin the process of language formation and actual reflection.

That trigger is the act of the soul picking out a "characteristic mark" or Merkmal from the flood of sensations.

The human being demonstrates reflection when the force of his soul operates so freely that in the whole ocean of sensations which floods the soul through all the senses it can, so to speak, separate off, stop, and pay attention to a single wave, and be conscious of its own attentiveness. ${ }^{42}$

This characteristic mark picked out by the soul is simultaneously the first act of reflection and the first word of the soul. Characteristic marks can be picked out in sensations of all kinds, but it is the sense of hearing which provides the first. Herder's example is that of Mendelssohn's in his critical reflections on Rousseau's discussion of language in the Discourse on the Origin of Inequality: a bleating lamb. ${ }^{43}$ No particular characteristics depicted to the individual's senses by the lamb passing before him stand out - it is white, soft, fuzzy - but his soul searches for one and finds it as soon as the lamb bleats. The sense of hearing, the middle sense between touch and sight, is the key to language, as Herder later argues in detail. ${ }^{44}$ The bleat is both a distinct concept and what Herder calls "an inward characteristic word" (innerliches Merkwort) according to which the individual will recognize the lamb the next time it passes before him (“Aha! You are the bleating one!"). ${ }^{45}$ The key here is that this language is entirely internal. For Herder, the genuine origin of language must be sought in the capacities of the human soul itself: a human being in the state of reflective awareness and whose soul is flooded with sensations cannot but begin to pick out characteristic marks as a means of ordering and making sense of those sensations. Via the sensorium commune, which operates by a kind of synaesthesia, the soul also learns to pick out characteristic marks relating to the other senses, and an inner language of characteristic marks slowly develops. ${ }^{46}$ This language is the only kind commensurate with the human sphere; it is fundamentally different from any animal language involving neither distinct

\footnotetext{
41 Ibid., 106-07.

42 Ibid., 87.

${ }^{43}$ Mendelssohn, Sendschreiben and den Herrn Magister Lessing in Leipzig, in Gesammelte Schriften Jubiläumsausgabe, ed. Fritz Bamberger et al. (Stuttgart: Friedrich Fromman Verlag, 1972), vol. 2, $107-08$.

${ }^{44}$ Herder, Treatise, $97 \mathrm{ff}$.

45 Ibid., 88.

${ }^{46}$ Ibid., 106-08, 133.
} 
ideas nor conscious awareness of them, but rather only obscure ideas of which the animal is not consciously aware.

Eventually, this language will start to become spoken language - the inner Merkwort for the individual becomes a Mitteilungswort or "communication word" for others - and this process will draw on the acoustic infrastructural groundwork already laid down by the language of feeling with its cries and interjections. ${ }^{47}$ The central point Herder wants to make, however, is that the emergence of spoken language does not represent the true origin of language. And it is this, he believes, that refutes Condillac and Rousseau, as well as Süßmilch (who argued for a divine origin of language), all of whom were caught in the circle in which reason is seen as essential to speech and speech as essential to reason. "Ratio et Oratio! If no reason was possible for the human being without language, good! then the invention of the latter is as natural, as old, as original, as characteristic for the human being as the use of the former." ${ }^{48}$ Inner language precedes and is the necessary condition for spoken language, and the use of reason begins with the first word of that inner language. For Herder, this process was self-evident. "If others found it unintelligible how a human soul was able to invent language, then it is unintelligible to me how a human soul was able to be what it is without precisely thereby, already even in the absence of a mouth and society, inevitably inventing language for itself." 49

\section{The Critique of réflexion en puissance}

Rousseau was one of those "others" who found it unintelligible that a human soul could invent language, and Herder certainly had him in mind. In fact, it is to Rousseau that Herder turns after presenting his notion of reflective awareness in order to demonstrate how it undermines Rousseau's notion of the "potential for reason" or réflexion en puissance, as Herder calls it. Part of Rousseau's strategy for defending his thesis of the natural goodness of man in the state of nature (as opposed to the wickedness he acquires in society), where he led an independent and self-sufficient existence, was to show how unnatural language, reason, and sociability were to him. For it was clear to Rousseau both that language, reason, and sociability were intimately connected and that they were the foundation of society. In the Discourse on the Origin of Inequality, Rousseau follows Condillac in maintaining that

\footnotetext{
47 Ibid., 97.

48 Ibid., 91.

${ }^{49}$ Ibid., 90.
} 
language (i.e., spoken language) and society are mutually necessary. ${ }^{50}$ Rousseau then describes just how difficult it would still have been, once language is invented, for a common language to become established-difficulties which demonstrate the virtual "impossibility that Languages could have arisen and been established by purely human means". ${ }^{51}$ He then reiterates the related problem of breaking out of the circle of ratio et oratio that Herder identifies and concludes:

Whatever may be the case regarding these origins, it is at least clear, from how little care Nature has taken to bring Men together through mutual needs and to facilitate their use of speech, how little it prepared their Sociability, and how little of its own it has contributed to all that men have done to establish its bonds. ${ }^{52}$

Although deprived of language, reason, or society, Rousseau's savage man is not thereby left in a state of helplessness. Rousseau agrees with Herder that what distinguishes humans from animals is their freedom. While both animals and humans have senses and ideas, the human being is able to acquiesce to or resist Nature's command, which is issued via these ideas, whereas animals are not, "and it is mainly in the consciousness of this freedom that the spirituality of his soul exhibits itself". ${ }^{53}$ But this freedom only fully emerges with the development of reason and language; in the state of nature, savage man is unaware of it and is in many ways no different from the animals around him. He begins with "purely animal functions" and, like animals, "[i]n instinct alone he had all he needed to live in the state of Nature". ${ }^{54}$ Concerned only with his physical self-preservation, Rousseau portrays his savage as "sating his hunger beneath an oak, slaking his thirst at the first stream, finding his bed at the foot of the same tree that supplied his meal, and with that his needs are satisfied." ${ }^{, 55}$ Far from needing reason and language, therefore, it is in fact thanks to a "very wise Providence that the faculties he had in potential were to develop only with the opportunities to exercise them". 56 These opportunities would come only later, engendered by entirely contingent "foreign causes"- highlighting the lack of necessity, but not inevitability", of the development of these faculties. ${ }^{58}$

\footnotetext{
${ }^{50}$ Rousseau, Discourse, 145. Cf. also 194, 207.

${ }^{51}$ Ibid., $145 \mathrm{ff} ., 149$.

52 Ibid., 149.

${ }^{53}$ Ibid., 141.

${ }^{54}$ Ibid., 142, 150.

55 Ibid., 134.

${ }^{56}$ Ibid., 150.

${ }^{57}$ For discussion, see Goldschmidt, Anthropologie et politique, 236-38.

${ }^{58}$ Ibid., 159, 139. In the Essay on the Origin of Languages, Rousseau writes: "Human associations are in large measure the work of accidents of nature; local floods, overflowing seas, volcanic eruptions, major earthquakes, fires started by lightning and destroying forests, everything that must have frightened and dispersed the savage inhabitants of a land must afterwards have brought them back together to restore in common their common
} 
The heart of Herder's disagreement with Rousseau concerns the idea that human reason could exist en puissance, as a potential, and thus be initially dormant. Herder recognizes that his own notion of reflective awareness, which is not yet reason or reflection, might seem rather close to Rousseau's idea of potential faculties. ${ }^{59}$ His response is to argue that Rousseau's réflexion en puissance sees reason as being suddenly transformed into actuality entirely in virtue of its first use and that this is nonsensical since, if the power is not present already, it cannot be used and applied. ${ }^{60}$ The background to this claim are Herder's related Leibnizian beliefs that: nature makes no jumps ${ }^{61}$, a faculty cannot therefore suddenly spring into action ${ }^{62}$, and what is less noticeable is not therefore nonexistent ${ }^{63}$. On Herder's reading, Rousseau is implying that because the faculty of reason is not apparent in savage man, it is therefore entirely dormant and effectively non-existent, whereas for Herder it is rather only at an earlier, less noticeable stage of development. Herder posits reflective awareness as a preliminary stage of the soul, before it invents inner language. Reflective awareness is a product of the different organization of human soul-forces and is present from the outset. While it is not fully-formed reason (Vernunft), it is the indispensable precondition for the emergence of reason and amounts to what Herder calls Vernunftmäßigkeit or rationality, which is another way of representing the difference between reflection (Besinnung) and reflective awareness (Besonnenheit). ${ }^{64}$ Considering the objection that possessing "rationality" must mean possessing mature "reason", Herder asks,

Does, then, thinking rationally mean thinking with developed reason? Does the claim that the infant thinks with awareness mean that he rationalizes like a sophist on his rostrum or the statesman in his cabinet? [...] But do they not, then, see that this objection merely denies [...] a more or less cultivated use of the forces of the soul, and not at all the positive fact of a force of the soul itself? And what fool will claim that the human being in the first moment of life thinks in the same way after many

\footnotetext{
losses”, in The Discourses, ed. Gourevitch, 274. See also Fragments politiques, in Euvres complètes, ed. Gagnebin and Raymond (Paris: Gallimard, 1964), vol. III, 533. It is worth noting that Rousseau's Essay was published only posthumously in 1781 , over ten years after Herder wrote his Treatise.

${ }^{59}$ Herder, Treatise, 86.

${ }^{60}$ Ibid., 85-6.

61 "Nothing happens at all at once; nature never makes a jump. Always from small to large ..." See Herder, Wahrheiten aus Leibnitz, in Herder und die Anthropologie, 36. Cf. Leibniz, New Essays on Human Understanding, ed. Peter Remnant and Jonathan Bennett (Cambridge: Cambridge University Press, 1996), 56.

62 "Faculty without act, mere capacities are nothing but fantasies which nature does not know - where does one find in the world a faculty without act? always a disposition to a tendency to an act". See Herder, Wahrheiten, 46. Cf. Leibniz, New Essays, 110.

63 "Engraved characters can be obscured, but not erased." See Herder, Wahrheiten, 45, 34ff. Cf. Leibniz, New Essays, 100. Herder notes later in the Treatise: "Reflective awareness governs even in the most sensuous condition, only less noticeably" (130, translation modified). And he asks: "is what is less noticeable therefore nonexistent?" (131).

${ }^{64}$ Ibid., 86.
} 
years' practice - unless one simultaneously denies the growth of all forces of the soul $[\ldots] ?^{65}$

Just as the capacity for reason develops and matures over the course of one's life, so too must it have developed over the course of human history, in particular with the assistance of spoken and written language, but while always being present and actual in some formsomething Herder believes Rousseau denies. Moreover, to speak of a capacity for reason and language being suddenly brought into actuality smacks of the kind of faculty psychology Herder opposed - reason is not an additional power. The human soul is one undivided power and is characterized, both ontogenetically and phylogenetically, by a disposition for rationality from the very outset, even if its growth towards mature reason is gradual. This is witnessed by the way the soul responds to the flooding of its senses - not as an instinctdriven animal whose soul-forces immediately zero in on what it is relevant for it, but rather in search of characteristic marks by which to order the wealth of data.

The refutation of potential faculties aside, Herder demonstrates how Rousseau's savage man in fact already possesses language - as inner language. The capacities Rousseau gives to his savage show that he has graduated from the state of reflective awareness to that of inner language: "the savage, the solitary in the forest, would necessarily have invented language for himself even if he had never spoken it", Herder claims. ${ }^{66}$ The evidence is to be found in the faculty of perfectibility, which Rousseau links to development of all the others, such as reason and language, but which is apparently dormant in the pure state of nature. ${ }^{67}$ Herder believes perfectibility is active in this state, in virtue of savage man's ability to learn from animals ${ }^{68}$, and claims that Rousseau thereby refutes himself through his very own words. $^{69}$

And now what has Rousseau not conceded to this natural human being! More than we want and need! The first thought - "Behold! That is something peculiar to the animal The wolf howls! The bear roars!" - this is already (thought in such a light that it could combine with the second thought, "That is something I do not have!") actual reflection [Reflexion]. And now the third and fourth thoughts - "Fine! That would

\footnotetext{
65 Ibid., 85 .

66 Ibid., 90.

${ }^{67}$ Rousseau, Discourse, 141, 159. I follow Victor Gourevitch in using "pure state of nature" to distinguish the pre-social state of nature from the social one. See Gourevitch, "Rousseau's Pure State of Nature", Interpretation 16, no. 1 (1988): 23-59.

${ }^{68}$ Roger Masters is of the same opinion [see Roger Master, The Political Philosophy of Rousseau (Princeton: Princeton University Press, 1968), 150] while Victor Goldschmidt maintains that this serves only to elucidate man's ability to raise himself to the level of animals' instincts by giving it the name of perfectibility, whereas none of the further developments of the latter, such as liberty, are apparent in this state. See Goldschmidt, Anthropologie et politique, $293 \mathrm{ff}$.

${ }^{69}$ Herder, Treatise, 94.
} 
also accord with my nature! I could imitate that! I want to imitate that! Thereby my species will become more perfect!" - what a mass of fine, inferentially connected reflections!, since the creature that was able to consider only the first of these necessarily already had a language of the soul!, already possessed the art of thinking which created the art of speaking. The ape always apes, but it has never imitated. ${ }^{70}$

The reflections Herder here puts in the mind of the savage are formulated as they are for rhetorical effect, but the underlying point remains the same: reflection and language, however primitive, are needed for imitation-something no animal does - and are evidence of the activity of rationality. Rousseau is thus wrong to claim that savage man is guided by instinct alone, for not only does he have no such instinct, but his ability to learn from animals clearly demonstrates a power transcending it.

\section{The Framework of Natural Law}

These criticisms of Rousseau are all made in Part I of the Treatise on Language, which is primarily concerned with demonstrating how the human soul, through its own forces, is capable of inventing language. The stronger point, that the human soul must necessarily invent language, is also present, but it is really in Part II that Herder turns his full attention to it. The title of Part II reads, "In what way the human being most easily could and had to invent language" and was a treatment of the second part of the prize question: "And by what means will they [i.e., men abandoned to their natural faculties] arrive at this invention?" ${ }^{, 71}$ Herder here considers the historical side of the origin and development of language and his analysis consists of a discussion of four natural laws governing it. We turn first, however, to what Herder meant by natural law, an understanding of which is essential to a proper grasp of both Part II and his philosophy of language as a whole.

In the Discourse on the Origin of Inequality, Rousseau distinguishes between two conceptions of natural law. The first is that of the "Roman Jurists" who construed it as a "Law which Nature imposes upon itself" and which amounts to "the expression of the general relations established by nature among all animate beings, for their common preservation." 72 The second is a prescriptive conception of natural law as "a rule prescribed to a moral being" "73, whose knowledge was secured through universal reason, and was

\footnotetext{
${ }^{70}$ Ibid., 95 (translation modified).

${ }^{71}$ Ibid., 127 (translation modified).

${ }^{72}$ Rousseau, Discourse, 126.

${ }^{73}$ Ibid.
} 
associated with the "Moderns", in particular Grotius and Pufendorf. ${ }^{74}$ Rousseau rejects the modern conception as it attributed to human beings capacities they could not possibly have had in the state of nature, requiring that savage man be "a very great reasoner and a profound Metaphysician." 75 Rousseau also rejects the very language of natural "law" since there are two conditions for its existence which can not both be met: "[a]11 we can very clearly see about this Law is not only that for it to be law the will of him whom it obligates must be able to submit to it knowingly; But also that for it to be natural it must speak immediately with the voice of Nature."76 Rousseau's alternative is to propose two "principles" operating "prior to reason" in the pure state of nature, namely, self-love and pity, which pre-reflectively guide savage man. ${ }^{77}$

We shall turn to these principles and the question of natural sociability when we discuss Herder's Second Natural Law. With respect to Herder's general conception of natural law, however, he essentially shares Rousseau's opinion. He agrees that natural law cannot consist in a prescriptive moral rule and that its operation cannot depend on its being consciously followed. ${ }^{78}$ He thus also agrees that whatever guides human beings in the state of nature must do so pre-reflectively. Unlike Rousseau, however, this does not lead Herder to dispense with the terminology of natural "law" and speak only of "principles" or "natural right". ${ }^{79}$ For Herder's conception of natural law extends far beyond the moral realm or even the "general relations among animate beings for their preservation". Like Rousseau, Herder sees nature as the product of a divine creator. But unlike Rousseau, Herder has a metaphysics informing his understanding of God's creation that is laid out in several short writings from the late 1760 s and which informs his discussion in the Treatise on Language ${ }^{80}$ Briefly, God necessarily realizes himself through the actualization of all that is possible in the divine

\footnotetext{
${ }^{74}$ E.g., "This then will appear a fundamental Law of Nature, Every Man ought, as far as in him lies, to promote and preserve a peaceful Sociableness with others, agreeable to the main End and Disposition of Human Race in General', Samuel Pufendorf, The Law of Nature and Nations, transl. Basil Kennet (London: Bonwicke et al, 1749), 108.

${ }^{75}$ Rousseau, Discourse, 126.

${ }^{76}$ Ibid., 127.

${ }^{77}$ Ibid., 127, $152 \mathrm{ff}$.

${ }^{78}$ While this is evident in the Treatise, in his early writings Herder repeatedly expresses the related view that most people are guided more by mores (Sitten) and moral feelings than by rules or principles, which he usually criticizes for their consequent inadequacy. See, e.g., How Philosophy Can Become More Universal and Useful for the Benefit of the People, in Herder, Philosophical Writings, 12-15.

${ }^{79}$ For discussion of Rousseau's preference for the term "natural right" over "natural law", see Gourevitch, "Introduction", in Rousseau, The Social Contract and Other Later Political Writings, ed. Gourevitch (Cambridge: Cambridge University Press, 1997), x-xii.

${ }^{80}$ A detailed discussion of Herder's metaphysics is beyond the scope of this essay. For analysis, see DeSouza, "Leibniz in the eighteenth century" and the first-rate study by Marion Heinz, Sensualistischer Idealismus: Untersuchungen zur Erkenntnistheorie und Metaphysik des jungen Herders (1763-1778) (Hamburg: Felix Meiner Verlag, 1994), esp. 81-101.
} 
thought in the form of the external physical universe, which becomes a natura operativa endowed with forces through which it functions and unfolds. ${ }^{81}$ It was Kant's hypothesis in his Universal Natural History and Theory of the Heavens (1755) of the orderly development of a divinely created physical universe, according to the necessary operation in matter of the Newtonian forces of attraction and repulsion and the laws of motion to which they gave rise, that left its greatest mark on Herder's conception of nature. ${ }^{82}$ Drawing on Leibniz's conception of the soul, but suitably modified to allow for genuine intermonadic communication and hence soul-body interaction, Herder construed the soul as endowed with forces through which it first constructed a physical body for itself (attraction and repulsion), secured nourishment for that body (expansion and contraction of living fibres), and sensuously interacted with the external world via its five senses and their media (light, sound, etc). ${ }^{83}$ Herder draws an analogy between the soul and God according to which it is only through the external body it is driven to build for itself that the soul fully realizes itself, engaging with the external world and developing its forces.

Part I of his Treatise is a further contribution to this theory of the human soul insofar as it attempts to prove how, given the very structure of its forces, it cannot but develop in such a way that leads to its inventing language, something indeed each child does every time it is "taught" language. ${ }^{84}$ Part II of the Treatise attempts to show how the original invention came about historically: just as the physical universe itself is the product of matter endowed with forces of attraction and repulsion moving according to laws of motion, so too does a soul, or rather many interacting souls, endowed with forces necessarily produce, according to the natural laws which emerge from these forces, not just language, but also society and culture. In postulating divinely endowed soul-forces, Herder's starting point is thus inescapably (and, for the later critical Kant, dogmatically) metaphysical; however, his real objective is, on this basis, to provide a plausible naturalistic and developmental account

\footnotetext{
${ }^{81}$ Herder, Grundsätze der Philosophie, in Herder und die Anthropologie, 52-4.

${ }^{82}$ See Grundsätze, 53-54; Gesetze der Welt: Gesetze der Körper, in Herder, Journal meiner Reise im Jahr 1769. Pädagogische Schriften, ed. Rainer Wisbert (Frankfurt: Deutscher Klassiker Verlag, 1997), 222. Kant, Allgemeine Naturgeschichte und Theorie des Himmels, in Kants Werke, ed. Königlich preußischen Akademie der Wissenschaften (Berlin: De Gruyter, 1968), vol. I, 225-26, 234. Herder also took from Kant the non-moral dependency of these laws on God, i.e., their absolute necessity concomitant with the creation of matter (227). Cf. Kant, Der einzig mögliche Beweisgrund zu einer Demonstration des Dasein Gottes, in Kants Werke, vol. 2 , 99-100.

${ }^{83}$ Grundsätze, 54; Gesetze der Welt, 222; Plato sagte: daß unser Lernen bloß Erinnerung sei in Heinz, Sensualistischer Idealismus, 175-79.

84 "Parents never teach their children language without the children constantly inventing it as well". See Herder, Treatise, 92.
} 
which effectively makes manifests an immanent natural purposiveness. ${ }^{85}$ The First Natural Law reads as follows: "The human being is a freely thinking, active being, whose forces operate forth progressively; thus is he a creature of language!" ${ }^{86}$ The first quality Herder mentions here is the free-thinking nature of humans. This harks back to his discussion of the particular organization of human soul-forces that are not limited in any way, unlike those of animals. Rousseau too endows his savage man with a capacity for freedom, but it is not initially realized in the pure state of nature, for savage man is not yet conscious of his freedom. As a result, he remains tethered to an instinct capable of refining itself by learning from the instincts of other animals, until that concatenation of foreign causes will conspire to set his faculty of perfectibility in motion and bring about the development of reason, language, and society. We have already considered Herder's critique of these ideas. What is important here, however, is first, that Herder's conception of human freedom in its first manifestation is an objective state of the individual's soul resulting from its structure and has nothing to do with any subjective awareness of one's freedom. In this it is like Rousseau's. But even more important is that, second, this structural freedom of the soul does not have to become self-conscious freedom to have real consequences (as Herder shows is the case with Rousseau's perfectible savage man). Rather, this very freedom is the necessary precondition of the invention of human language. The lack of determinacy of human soul-forces must be seen in its proper context for its genuine purpose to be discovered. For as Herder notes in the preamble to Part II, "Nature gives no forces in vain." 87

\section{Inner Language and misericordia}

The elucidation of this context is the objective of Herder's discussion of the First Natural Law. Herder's portrait of the human being in the state of nature (a term he never uses but the idea of which he is clearly implying) is the familiar one of misericordia from the modern natural law tradition, especially Pufendorf, and which he had invoked in Part I. Here, Herder explores the dynamics of the predicament. In a word, need is the catalyst for the "progressive operating forth" of the soul-forces referred to in the First Natural Law.

If understanding and reflective awareness is the natural gift of his kind, this had to express itself immediately when the weaker sensuality and all the poverty of his lacks expressed itself. The instinctless, miserable creature which came from nature's hands

\footnotetext{
${ }^{85}$ I owe this clarification and its formulation to the helpful comments of the anonymous reviewer.

${ }^{86}$ Ibid., 127 (translation modified).

${ }^{87}$ Ibid.
} 
so abandoned was also from the first moment on the freely active, rational creature which was destined to help itself, and inevitably had the ability to do so. ${ }^{88}$

Just as Rousseau had seen it as thanks to "a very wise Providence" that savage man's potential faculties were initially dormant, Herder sees the very same providence behind the dialectic of need and development in the human soul operating from the outset. While the condition of misericordia was the general catalyst, the flooding of the senses with data from the external world was the particular one that activated the sensorium commune and set the soul in search of that characteristic mark that would be "the first moment of reflection [and] the moment for the inward emergence of language." 89 As Herder puts it, "[t]he whole of nature storms at the human being in order to develop his senses until he is a human being." 90 Herder also reflects something of Rousseau's favourable portrayal of savage man when he argues that it was in fact only the human being as it first emerged from the hands of nature, fresh and vigorous and, most importantly, with its undivided soul and undeveloped forces (as opposed to the specialized, weakened forces of human beings in modern society with its division of labour) that could ever have invented language. ${ }^{91}$ Even the lack of society and its stimulations contributed to the process such that "[the soul] stimulated itself all the more mightily, gave itself all the activity of sensation and thought which it had to give itself in view of the inner impulse and external demands [...] There language was born with the whole unfolding of the human forces." 92 This was the tool through which nature had compensated human beings for their lack of instinct, a tool commensurate with their needs and those external demands in a way no instinct could be. ${ }^{93}$

The clearest demonstration of the sufficiency of language was to be found not in the original act of reflection and inner word through which it was invented, but rather in its subsequent development. Governing this development is what Herder calls "a great law of the natural order": "the whole chain of conditions in the human soul is of such a kind that each of them forms language further." 94 The human being in the state of nature does not pick out characteristic marks as isolated acts of reflection; rather, the acquisition of each belongs to a process of learning and together they make up an interconnected collection.

\footnotetext{
${ }^{88}$ Ibid., 128 (translation modified).

${ }^{89}$ Ibid., 129, 128 (translation modified).

${ }^{90}$ Ibid., 129.

${ }^{91}$ Ibid., 129, 138.

92 Ibid., 138.

93 Ibid., 128.

${ }^{94}$ Ibid., 129.
} 
[The human being is] the most ignorant creature when he comes into the world, but immediately he becomes nature's apprentice in a way that no animal does; not only does each day teach the next, but each minute of the day teaches the next, each thought the next. It is an essential knack of his soul to learn nothing for this moment, but to marshal everything either along with what it already knew or in readiness for what it intends to link with it in the future. His soul hence takes into account the store which it has already collected or still intends to collect. And in this way the soul becomes a force of steadily collecting. Such a chain continues on until death. [He is,] so to speak, never the whole human being; always in development, in progression, in the process of perfection. ${ }^{95}$

Herder gives examples of the kinds of things the characteristic marks of which the human being would collect, by observation of animals or experience: edible kinds of food, types of plants, the sounds of dangerous animals. They all develop and enrich its inner language, and yet, as Herder highlights, "it is only the life of a single human being!" "26 Language is thus the instrument of the constant progress marking a single human life — of the "law of perfection" (Gesetz der Vervollkommung). ${ }^{97}$ It is here that Herder's connection to the German Aufklärung, whose religious and theological dimension was fundamental, can be most clearly seen. ${ }^{98}$ Human beings, qua language creatures, are ineluctably called to perfect themselves, thereby fulfilling God's will and plan for them. The crucial difference, however, between Herder and earlier Aufklärer such as Christian Wolff, for whom the principle of Vervollkommung was paramount ${ }^{99}$, is that in Herder's conception of human nature, the process of perfection operates naturally, via the forces of the human soul and their unfolding, rather than via the individual's rational knowledge and conscious following of a principle of perfection.

\section{Language and Sociability}

This progress and learning does not come to an end with the life of the human being in the state of nature, for just as the inner word is destined to become a word of communication (Mitteilungswort), so does language become an instrument for education. ${ }^{100}$

\footnotetext{
95 Ibid., 130.

${ }^{96}$ Ibid., 133.

${ }^{97}$ Ibid., 131 (translation modified).

${ }^{98}$ For discussion see Panajotis Kondylis, Die Aufklärung im Zeitalter des neuzeitlichen Rationalismus (Hamburg: Felix Meiner Verlag, 2002/1981), 537ff.

99 "Do what makes you and your condition, or that of others, more perfect; omit what makes it less perfect." See Wolff, Vernünfftige Gedancken von der Menschen Thun und Lassen, zu Beförderung Ihrer Glückseeligkeit (Frankfurt, 1720), §12.

${ }^{100}$ I thus disagree with Aarselff's interpretation that Herder makes language a "silent, private, non-social discourse of the mind." See Aarsleff, "Herder's Cartesian Ursprung vs. Condillac's Expressivist Essai", in Language Philosophies and the Language Sciences, ed. Gambarara et al. (Münster: Nodus, 1996), 171ff., 174; Jürgen Trabant develops a similar interpretation, see Trabant, "Inner Bleating: Cognition and Communication in
} 
But in order to become this, Herder needs to account for what brings humans together, given that his account of language has thus far consisted exclusively of its emergence within the soul of a single human being. The Second Natural Law addresses this question: "The human being is in his destiny a creature of the herd, of society. Hence the progressive formation of a language becomes natural, essential, necessary for him."101 Arguments for human beings' natural sociability would have been familiar to Herder, including those of Aristotle and Grotius. Among his contemporaries, in a letter to Kant from 1768, Herder directly links his overcoming of his early enthusiasm for Rousseau, and his concomitant acceptance of natural sociability, to Hume, whom he calls "in the truest sense of the term [...] a philosopher of human society." 102 But Hume never actually examines natural sociability aside from references to humans being necessarily born into a family-society" and to the "fellowfeeling" or "benevolence" that he recognizes as a "principle in human nature". ${ }^{104}$ Herder also considered Hume to be a "bad metaphysician", 105 largely because, unlike him, Herder was committed, following Leibniz, to the need for speculative metaphysics to help uncover the real world that informs the apparent one, as he puts it on repeated occasions. ${ }^{106}$ Inspired by Newton and Kant's cosmogony, Herder wholeheartedly shared the eighteenth-century project of a "science of human nature" (Hume) or an "experimental physics of the soul" (D'Alembert) and the attempt to explain the observable phenomena of human experience according the operation of scientific principles or natural laws. ${ }^{107}$ But this attempt was for Herder inseparable from the equivalent need for an underlying metaphysics accounting for these principles and laws. It is for this reason that he turned to another thinker in his

the Language Origin Discussion”, Herder Yearbook 2000, ed. Menges et al. (Stuttgart: Metzler, 2000), here 9ff. These amount to distorted readings of Herder resulting from a failure to situate the origin of inner language of Part I within the broader context of the Treatise. For inner language is only a preliminary step, ontogenetically (cf. note 82) and phylogenetically, in the development of language as we know it. And it is inseparable from the analysis of Part II according to which language is an instrument of sociability and education central to the survival and flourishing of the individual and species.

${ }^{101}$ Herder, Treatise, 139.

${ }^{102}$ Herder, Briefe, vol. I, 119.

${ }^{103}$ Hume, A Treatise of Human Nature, ed. David Fate Norton and Mary J. Norton (Oxford: Oxford University Press, 2000), 316; Hume, An Enquiry Concerning the Principle of Morals, ed. Tom Beauchamp (Oxford: Oxford University Press, 1998) 88; Hume, "Of the Origin of Government", Essays, moral, political, and literary, ed. Eugene F. Miller (Indianapolois: Liberty Fund, 1985), 37.

${ }^{104}$ Hume, Enquiry, 116; Appendix, 166.

${ }^{105}$ Herder, Review of Jame's Beatties Essay on the Nature and Immutability of Truth, in Opposition to Sophistry and Scepticism, in Herder, Sämtliche Werke, ed. Bernard Suphan, 33 vols (Berlin: Weidmann 1877$1913)$ vol. 5, 461.

${ }^{106}$ Herder, Wahrheiten aus Leibniz, 32; Herder, Phänomene des Wahren und Schönen, in Sämtliche Werke, vol. 8,112 .

${ }^{107}$ Hume, An Enquiry concerning Human Understanding, ed. Tom Beauchamp (Oxford: Oxford University Press, 1999), 87; D'Alembert, Preliminary Discourse to the Encylopedia of Diderot, ed. Richard Schwab (Chicago: Chicago University Press, 1995), 84. 
discussion of natural sociability, who offered both a naturalistic account of it and who situated it within the context of a providentially designed natural order. That thinker was Shaftesbury. ${ }^{108}$

In the same letter to Kant in which he mentions Hume, Herder asks, "But why do you forget my beloved philosopher, in addition to your pair [i.e., Montaigne and Hume] the third man? who has just as much social temperament, just as much human philosophy - the friend of our old Leibniz, who owed so much to him and who liked to read him so much [...] in short, the Earl of Shaftesbury." ${ }^{109}$ Herder had already noted in his Truths from Leibniz the "instinct for society" which Leibniz attributed to humans, ${ }^{110}$ but in Shaftesbury he found the kind of detailed discussion of the state of nature and natural sociability that resonated with him. Beyond the textual evidence for Shaftesbury's influence, discussed below, Herder also made explicit reference in a letter to those ideas of Shaftesbury that were central to the Treatise just as he was scrambling to complete it to send off to the Berlin Academy by December 1770. Defending Shaftesbury against the charge of atheism made by the French author Delisle de Sales, Herder writes,

Shaftesbury is for him an atheist, whom he constantly rails against without having properly read him: but an atheist who preaches nothing so much as order, harmony, highest wisdom in the structure of the whole world, who above all speaks of optimism such that he touches the heart where Leibniz only speaks of it to the understanding, indeed who finally conceived of the great system of virtue which was the greatest triumph of providence - this Atheist with his great world spirit (which for me is the most splendid name for God) is worth more to me than ten such petty masters of philosophy. ${ }^{111}$

It is on Shaftesbury more than any other thinker that Herder depends for his conception of providence and the image of the great "household of nature" (Haushaltung der Natur) which returns on numerous occasions throughout the Treatise. ${ }^{112}$

In The Moralists, Shaftesbury speaks of nature along these lines, through the character of Theocles, as evidence of the providential design behind its autonomous operation: "Such then [...] is the admirable Distribution of NATURE, her adapting and adjusting not only the Stuff or Matter to the Shape and Form, and even the Shape it-self and

\footnotetext{
${ }^{108}$ The importance of Shaftesbury for Herder's conception of sociability in the Treatise has not been fully recognized in the secondary literature. Cf. Pross, "Kommentar", in Herder, Abhandlung, 131 and Neis, Anthropologie, 425 who provide only brief discussions.

${ }^{109}$ Herder, Briefe, vol. I, 119.

${ }^{110}$ Herder, Wahrheiten aus Leibnitz, 43; cf. Leibniz, New Essays, 93.

${ }^{111}$ Herder, Briefe, vol. I, 217 (12 September 1770).

${ }^{112}$ Ulrich Gaier's insightful discussion of the "religious dimension" of the Treatise mentions only Kant (of the Allgemeine Naturgeschichte) among the philosophical sources of Herder's Haushaltung der Natur. See Gaier, Herders Sprachphilosophie, 141-43.
} 
Form to the Circumstance, Place, Element or Region; but also the Affections, Appetites, Sensations, mutually to each other, as well as to the Matter, Form, Action, and all besides". ${ }^{113}$ In response to a question from Philocles with respect to why animals, but not humans, have instinct, Theocles is able to provide an example of this "distribution of nature" in action. Whereas the young of most animals immediately have some degree of selfsufficiency, the human infant is "the most helpless, weak, infirm". He continues,

Where is the loss in such a Species? Or what is Man the worse for this Defect, amidst such large Supplies? Does not this Defect engage him the more strongly to Society, and force him to own that he is purposely, and not by accident, made rational and sociable; and can not otherwise increase or subsist, than in that social Intercourse and Community which is his natural State? Is not both conjugal Affection, and natural Affection to Parents, Duty to Magistrates, Love of a common City, Community, or Country, with the other Dutys and social Parts of Life, deduc'd from hence, and founded in these very Wants? What can be happier than such a Deficiency, as is the occasion of so much Good? ${ }^{114}$

The central lesson Herder drew from these ideas was that nature realized its objectives through human needs, and that natural sociability was an outcome of them. We have already seen how the dialectic of need and development operates in the invention of language. In his discussion of the Second Natural Law, Herder shows how need or "Defect" works to develop not just the human being's rationality (Vernunftmäßigkeit), but also his socially affective nature.

Herder turns to the subject of human reproduction upon enunciating his second law, adducing the relevant facts: females have no season of heat, male reproductive force is constant - the same ones Rousseau uses to justify the sufficiency of chance encounters between the sexes for the survival of the species. ${ }^{115}$ Herder, however, asks why, if storks and pigeons have marriages (Ehen), humans, for many more reasons too, should not also. Humans, as weaker, feebler, more naked creatures, also require caves for shelter. And, thanks to causes linked to reproduction, Herder explains, these naturally become common caves. ${ }^{116}$ Next, again referring to human weakness, Herder speaks of the social assistance the human female requires when pregnant, in comparison to the ostrich which can lay its eggs in the desert. Finally, the human infant, which Herder refers to as a suckling, is very much "a vassal

\footnotetext{
${ }^{113}$ Shaftesbury, The Moralists, a Philosophical Rhapsody, in Characteristicks of Men, Manners, Opinions, Times, ed. Douglas Den Uyl (Indianapolis: Liberty Fund, 2001), 172-73. See also p. 83 for the conception of nature as an ordered whole.

${ }^{114}$ Ibid., 174.

${ }^{115}$ Rousseau, Discourse, 156, 161.

${ }^{116}$ Herder, Treatise, 139.
} 
of human help and societal pity." "117 Echoing Shaftesbury's "distribution of nature", all this leads Herder to exclaim, "To whom does not "nature's household management in the interest of humanity's socialization" become obvious from these facts? And indeed a natural household-management that is as immediate, as close to instinct, as could be the case with a creature possessed of awareness!" 118 Herder is pitting Shaftesbury's conception of nature against Rousseau's.

Herder's main argument against Rousseau's rejection of natural sociability, however, was not one based purely on the utility of the family, for Herder does not engage in detail with Rousseau's careful self-interest based arguments against the existence of the family in the state of nature, which adduce humans' natural vegetarianism, the mother's ability to carry the child with her while she foraged for food or fled danger, etc. ${ }^{119}$ Rather, Herder takes issue with the absence of parental affection for children in Rousseau's pure state of nature where, Herder recounts, the mother who is relieved to be delivered of the burden that cost her so much "throws it away" and the father, whose lust has been satisfied, and who has no reason to concern himself further with mother and child, goes off into the forest seeking a new object of his animal enjoyment. ${ }^{120}$ Rousseau with his principle of self-love (amour de soi), no less than "our coarse Epicureans" (i.e., Hobbes, as well as La Mettrie, Helvétius, D’Holbach) as Herder calls them, wants to explain everything "from blind pleasure or immediate selfinterest [Eigennutz]". ${ }^{121}$ Herder's key point here is that pleasure or self-interest alone would never have secured the survival of the species. For the baby entering the world in a state of misericordia is certainly not helping secure its self-interest by whining and crying and being generally troublesome: "he needs pity without being able to make himself in the least deserving of it". ${ }^{122}$ The self-interest of the parents would hardly direct them to expend all the time and effort required to raise the child. But this is not the way of nature, Herder insists. Self-interest alone "can in no way explain the feeling of parents towards their children [...] [a]nd the strong bonds that this produces".

How quite opposite is the order of nature here, with animals and with human beings, and how much more wise. Precisely the pains and troubles increase maternal love! Precisely the infant's lamentableness and unamiableness, the weak, frail quality of his

\footnotetext{
117 Ibid.

${ }^{118}$ Ibid., 140.

${ }^{119}$ Rousseau, Discourse, 145, 212-16.

${ }^{120}$ Herder, Treatise, 140.

121 Ibid.

${ }^{122}$ Ibid. (translation modified).
} 
nature, the troublesome, vexing effort of his upbringing doubles the strivings of his parents! ${ }^{123}$

Human need is again the catalyst for human development. Following Shaftesbury, Herder asserts, "nature [...] knows 'how to make strength out of weakness in the whole of the species". ${ }^{124}$ Not only was the subjectively felt need of the individual human being a catalyst for the development of language, but the objectively felt needs of others also become a catalyst for the emergence of those affections and feelings which are the basis of natural sociability. The capacity for pity that Rousseau gives to savage man necessarily entails the capacity for parental affection and hence sociability. ${ }^{125}$ In the words of Shaftesbury, "if natural Affection and the Care and Nurture of the Offspring be natural, Things standing as they do with Man, and the Creature being of that Form and Constitution he now is: it follows, 'That Society must be also natural to him'; And 'That out of Society and Community he never did, nor ever can subsist." ${ }^{126}$ In sum, the forces of the human soul, catalyzed by need, unfold both the rationality and language and the affectively rooted sociability which are in turn the basis of human society and culture.

In the remainder of the Treatise, Herder explores how language fulfills its destiny in becoming not just a tool of the progress of the individual, but also a tool of the education of one's children. Language becomes the storehouse of human beings' knowledge, which is continually transmitted, building an edifice that continues to grow and to bring about human development and progress in a way that contrasts with the bee that builds its hive today in the way it always has and will. Herder explores how from one original language many are formed (Third Natural Law) and how all languages together constitute a chain of the education (Bildung) of humanity (Fourth Natural Law). These later discussions are of great interest and significance and have not yet been accorded the scholarly attention they deserve. While I do not have the space to give them their due here, I will, by way of conclusion, outline one that is highly relevant to our concerns in this paper.

\footnotetext{
${ }^{123}$ Ibid. In the Grundsätze der Philosophie (1769) Herder also defends natural sociability, opposing it to "Rousseau's natural man [Naturmensch]", but interestingly subordinating it to "self-preservation [Selbsterhaltung]", a view he abandons here, perhaps under Shaftesbury’s influence. See Grundsätze, 230. 124 Ibid.

${ }^{125}$ Herder notes Rousseau gives animals a feeling of tenderness towards offspring, but denies it to humans (145). Cf. Rousseau, Discourse, 152. This contrasted not just with Shaftesbury, but with Hume also (who was probably echoing the former): "Tenderness to their offspring, in all sensible beings, is commonly able alone to counterbalance the strongest motives of self-love, and has no manner of dependence on that affection", Enquiry concerning the Principles of Morals, 167.

${ }^{126}$ Shaftesbury, The Moralists, 179.
} 
Although Herder critically engages with Rousseau throughout his Treatise, he seems insensitive to the fundamental political and social critical dimension of Rousseau's discussion of the pure state of nature. Herder did, to his credit, acknowledge this dimension in a letter to Hamann from 1768 where he admitted that he could not unravel the problem in Rousseau of humans advancing "from the state of nature to the present evil of the world" as a result of the "treasure of capacities and inclinations etc." in their nature. If, to secure their happiness, this treasure was meant to remain locked up, Herder asks, "why did God give [them] this seed of straying [Irrsal]?" ${ }^{127}$ For Herder, that human nature was intended by God to unfold itself was clear, as he insists later in the letter and as we have seen in the Treatise. ${ }^{128}$ But in the discussion of the Third Natural Law, and the multiplication of languages, Herder responds to Rousseau's challenge. He rejects Rousseau's tracing of the wars that resulted in civil society to the institution of property. Instead, he argues that it is the human capacity to form "an opposed nature, habit, and language" that is the true origin of such wars. ${ }^{129}$ For the human in the state of nature, having language, is no "Rousseauian forest man", and having a family language, is no "Hobbesian wolf". ${ }^{130}$ And given these linguistic and social conditions, interfamily disagreements can arise, spiral into conflicts and separations/migrations, and ultimately engender deep-seated "familial and national hatred" while giving rise to new languages. Herder rejects the thesis that property relations could be the source of the first wars; humans at these early stages are far more concerned with family and tribal pride and honour. ${ }^{131}$ Herder's picture of human history is thus far from one of untainted progress and social harmony. While he develops a trenchant critique of politics in his own day in other works, bemoaning the culturally stultifying effects of absolutism, ${ }^{132}$ what is of interest in this brief overview of his response to the political Rousseau is his closeness to him. Like Rousseau, Herder rejects original sin, and like Rousseau, he sees the first human discord and development of vices as instead the product of humans themselves. But while Herder thus also agrees with Rousseau about humans' natural goodness, this in no way tempts him to

\footnotetext{
${ }^{127}$ Herder, Briefe, vol. I, 97.

${ }^{128}$ Employing the image of the tree of knowledge, Herder writes, "what good or bad is the tree of knowledge? [...] It is the risk which man took to extend himself beyond his limits, to gather knowledge, to enjoy strange fruit, to imitate other creatures, to raise his reason, and to want to be himself a collection of all instincts, all abilities, all forms of enjoyment, to be like God (no longer an animal) and to know." Herder, Briefe, vol. I, 98. ${ }^{129}$ Herder, Treatise, 151.

${ }^{130}$ Ibid.

${ }^{131}$ Ibid., 152.

${ }^{132}$ See esp. Herder, Auch eine Philosophie der Geschichte zur Bildung der Menschheit, in Herder, Schriften zu Philosophie, Literatur, Kunst und Altertum 1774-1787, ed. Jürgen Brummack and Martin Bollacher (Frankfurt: Deutscher Klassiker Verlag) 9-107; but also the remarkable fragment Gedanken bei Lesung Montesquieus, in Herder, Journal meiner Reise im Jahr 1769. Pädagogische Schriften, 204-08.
} 
develop an ontology whereby that original natural goodness alone might direct his understanding of nature's ends. For it is clear to Herder that the human telos involves the full development of the soul's powers both individually and collectively in culture and civilization. This view is of course given heft by his metaphysics, but it is at the same time noteworthy that Herder does not use the latter to paper over both the good and the bad that human nature can produce. He simply accepts the bad as an inescapable aspect of a process which is nonetheless outweighed by the good. 